\title{
Nitratireductor basaltis sp. nov., isolated from black beach sand
}

\author{
Kyoung-Ho Kim, ${ }^{1}$ Seong Woon Roh, ${ }^{1,2}$ Ho-Won Chang, ${ }^{1}$ \\ Young-Do Nam, ${ }^{1,2}$ Jung-Hoon Yoon, ${ }^{1}$ Che Ok Jeon, ${ }^{3,4}$ Hee-Mock Oh ${ }^{1}$ \\ and Jin-Woo Bae ${ }^{1,2,4}$ \\ 1Biological Resources Center, KRIBB, Daejeon 305-806, Republic of Korea \\ ${ }^{2}$ Korea University of Science and Technology, Daejeon 305-333, Republic of Korea \\ ${ }^{3}$ Department of Life Science, Chung-Ang University, Seoul 156-756, Republic of Korea \\ ${ }^{4}$ Environmental Biotechnology National Core Research Center, Gyeongsang National University, \\ Jinju 660-701, Republic of Korea
}

Correspondence Jin-Woo Bae baejw@kribb.re.kr

\begin{abstract}
A Gram-negative, coccoid- or rod-shaped bacterium was isolated from black sand collected from Soesoggak beach, Jeju Island, Korea. The isolate, designated $\mathrm{J}^{\top}$, grew at $15-45{ }^{\circ} \mathrm{C}$, at $\mathrm{pH} 5.5-$ 10.0 and in $0-8 \% \mathrm{NaCl}$. It was oxidase- and catalase-positive. Strain $\mathrm{J}^{\top}$ reduced nitrate to nitrite, but did not reduce nitrite to nitrogen gas. Phylogenetic analysis of the 16S rRNA gene sequence showed that strain $\mathrm{J}^{\top}{ }^{\top}$ was closely related to Nitratireductor aquibiodomus $\mathrm{NL} 21^{\top}$ and belonged to the genus Nitratireductor. Major cellular fatty acids were $\mathrm{C}_{18: 1} \omega 7 \mathrm{c}(82.0 \%)$, $\mathrm{C}_{19: 0} \omega 8 \mathrm{c}$ cyclo $(4.3 \%)$ and $\mathrm{C}_{18: 0}(4.0 \%)$, a profile that is typical of members of the genus Nitratireductor and distinct from those of other genera in the family Phyllobacteriaceae. Differences in physiological characteristics and fatty acid profiles, as well as low DNA-DNA hybridization values, further established that strain $\mathrm{J}^{\top}$ was distinct from $N$. aquibiodomus NL21 ${ }^{\top}$. Thus, strain $\mathrm{J}^{\top}\left(=\mathrm{KCTC} 22119^{\top}=\mathrm{JCM} 14935^{\top}\right)$ should be classified as the type strain of a novel species in the genus Nitratireductor, for which the name Nitratireductor basaltis sp. nov. is proposed.
\end{abstract}

The genus Nitratireductor was established by Labbé et al. (2004), who proposed Nitratireductor aquibiodomus, a novel species comprising a nitrate-reducing strain, $\mathrm{NL} 21^{\mathrm{T}}$. This strain was isolated from a marine denitrification system fed with methanol (Labbé et al., 2003). This strain differed from members of other genera of the family Phyllobacteriaceae (Mergaert \& Swings, 2005, 2006) with respect to a relatively low DNA G + C content (57 vs 60 $64 \mathrm{~mol} \%$ for other representatives of the family) and in its fatty acid profile (Labbé et al., 2004). Currently, only one species has been described in the genus Nitratireductor. In this study, strain $\mathrm{J3}^{\mathrm{T}}$, a Nitratireductor-like strain isolated from black sand from Soesoggak beach, Jeju Island, Korea, was characterized.

Strain $\mathrm{J3}^{\mathrm{T}}$ was isolated from black sand by using the standard dilution plating method and was cultured routinely on marine agar 2216 (MA; Difco) at 30 or $37{ }^{\circ} \mathrm{C}$. The Gram reaction was performed using the nonstaining method described by Buck (1982). Cell morphology and motility were observed under a Nikon phase-

The GenBank/EMBL/DDBJ accession number for the 16S rRNA gene sequence of strain $\mathrm{J}^{\top}{ }^{\top}$ is EU143347. contrast microscope at $\times 1000$ magnification with cells grown for 3 days at $37{ }^{\circ} \mathrm{C}$ on MA. Growth on R2A (Difco) and trypticase soy agar (TSA; Difco) was also evaluated at $37{ }^{\circ} \mathrm{C}$. Growth at different temperatures $(4,10,15,25,30$, 37,41 and $\left.45{ }^{\circ} \mathrm{C}\right)$ and $\mathrm{pH}(\mathrm{pH} 4.0-13.0$ at intervals of 0.5 $\mathrm{pH}$ units) were assessed on MA and marine broth (Difco), respectively. Salt tolerance was tested in trypticase soy broth containing $0.5-30 \%(\mathrm{w} / \mathrm{v}) \mathrm{NaCl}$. Strain $\mathrm{J3}^{\mathrm{T}}$ was Gram-negative and non-motile. Growth occurred on R2A, TSA and MA. After 3 days incubation on MA at $30^{\circ} \mathrm{C}$, colonies were circular, smooth, creamy and convex, 0.5$2.0 \mathrm{~mm}$ in diameter. Strain $\mathrm{J}^{\mathrm{T}}$ was able to grow at $15-$ $45{ }^{\circ} \mathrm{C}$, at $\mathrm{pH} 5.5-10.0$ and in $0-8 \% \mathrm{NaCl}$.

DNA was extracted using a commercial genomic DNA extraction kit (G-spin; iNtRON Biotechnology). PCRmediated amplification using PCR Pre-Mix (Solgent) of the 16S rRNA gene and sequencing of the purified PCR product with a PCR purification kit (Cosmo genetech) were carried out according to Yoon et al. (1998). Phylogenetic analyses were carried out according to Kim et al. (2006). The $16 \mathrm{~S}$ rRNA gene sequences of related taxa were aligned using the program CLUSTAL_X (Thompson et al., 1997). The program MEGA3 (Kumar et al., 2004) was 
used for tree construction. The neighbour-joining method was used to construct phylogenetic trees (Saitou \& Nei, 1987) and distance matrices were calculated using Kimura's two-parameter model (Kimura, 1980). Bootstrap analysis was performed based on 1000 replications (Felsenstein, 1985). DNA-DNA relatedness was determined using photobiotin-labelled DNA probes and microwell plates as described previously (Roh et al., 2008).

Comparative 16S rRNA gene sequence analyses revealed that strain $\mathrm{J}^{\mathrm{T}}$ showed the highest $16 \mathrm{~S}$ rRNA gene sequence similarity to $N$. aquibiodomus $\mathrm{NL} 21^{\mathrm{T}}(97.0 \%)$ and it showed similarities of less than $96.3 \%$ to the type strains of species of other genera in the family Phyllobacteriaceae of the Alphaproteobacteria. The phylogenetic tree also showed that strain $\mathrm{J}^{\mathrm{T}}$ formed a monophyletic group with a bootstrap value of $97 \%$ with N. aquibiodomus $\mathrm{NL}^{\mathrm{T}} 1^{\mathrm{T}}$ and could be distinguished clearly from members of related genera (Fig. 1). The DNA-DNA relatedness between $\mathrm{J}^{\mathrm{T}}$ and N. aquibiodomus $\mathrm{NL} 21^{\mathrm{T}}$ was less than $10 \%$. Low $16 \mathrm{~S}$ rRNA gene sequence similarity and DNA-DNA relatedness confirmed that strain $\mathrm{J}^{\mathrm{T}}$ was distinct from $N$. aquibiodomus $\mathrm{NL} 21^{\mathrm{T}}$ at the species level.

Cellular fatty acids were analysed from cells of $\mathrm{J}^{\mathrm{T}}$ and $\mathrm{N}$. aquibiodomus $\mathrm{NL} 21^{\mathrm{T}}$ grown on TSA (Difco) for 3 days at $30{ }^{\circ} \mathrm{C}$. Cellular fatty acids were analysed according to the protocol of the Sherlock Microbial Identification system (Sasser, 1990) using GC. The fatty acid pattern of strain J3 ${ }^{\mathrm{T}}$ was similar to that of N. aquibiodomus NL21 ${ }^{\mathrm{T}}$ (Table 1), and the strain could therefore be affiliated to the genus Nitratireductor; however, the fatty acid profiles of members of the genus Nitratireductor differed from those of members of related genera in the family Phyllobacteriaceae, as clarified previously (Labbé et al., 2004). However, some differences in fatty acid content were observed between strain $\mathrm{J}^{\mathrm{T}}$ and $N$. aquibiodomus $\mathrm{NL} 21^{\mathrm{T}}$; strain $\mathrm{J}^{\mathrm{T}}$ had a smaller amount of $\mathrm{C}_{18: 0}$ and a larger amount of summed feature 3 compared with $N$. aquibiodomus NL21 $1^{\mathrm{T}}$. The absence or presence of certain minor fatty acids also enabled the strains to be differentiated from each other (Table 1).

Catalase activity was determined by bubble production in $3 \%(\mathrm{v} / \mathrm{v}) \mathrm{H}_{2} \mathrm{O}_{2}$ and oxidase activity was determined using $1 \%(\mathrm{w} / \mathrm{v})$ tetramethyl $p$-phenylenediamine. The $\mathrm{G}+\mathrm{C}$ content of the chromosomal DNA was determined by the thermal denaturation method as described previously (Gonzalez \& Saiz-Jimenez, 2002). Physiological characteristics of strain $\mathrm{J}^{\mathrm{T}}$, including nitrate-reducing ability, were determined with API 20NE, API ZYM and API $50 \mathrm{CH}$ galleries, according to the instructions of the manufacturer (bioMérieux). Differential physiological characteristics of strain $\mathrm{J}^{\mathrm{T}}$ and $N$. aquibiodomus, the type species of the genus Nitratireductor, are listed in Table 2. Both species reduced nitrate to nitrite, but did not reduce nitrite to nitrogen gas. Both species were negative for urease, unlike most members of related genera. The DNA G $+C$ content of strain $\mathrm{J}^{\mathrm{T}}$ was $56.7 \pm 1.3 \mathrm{~mol} \%$, which is similar to that for $N$. aquibiodomus $\mathrm{NL} 21^{\mathrm{T}}$. In contrast to $N$. aquibiodomus $\mathrm{NL} 21^{\mathrm{T}}$, strain $\mathrm{J}^{\mathrm{T}}$ assimilated gluconate, mannitol and maltose, but did not assimilate citrate. Strain $\mathrm{J}^{\mathrm{T}}$ showed $\alpha$ and $\beta$-galactosidase activities, which are absent in most members of the family Phyllobacteriaceae and in $N$. aquibiodomus $\mathrm{NL}^{2} 1^{\mathrm{T}}$ (Labbé et al., 2004).

Phenotypic, chemotaxonomic and phylogenetic analyses established that the isolate could be affiliated to the genus Nitratireductor and suggest that it represents a novel species of the genus, for which the name Nitratireductor basaltis sp. nov. is proposed.

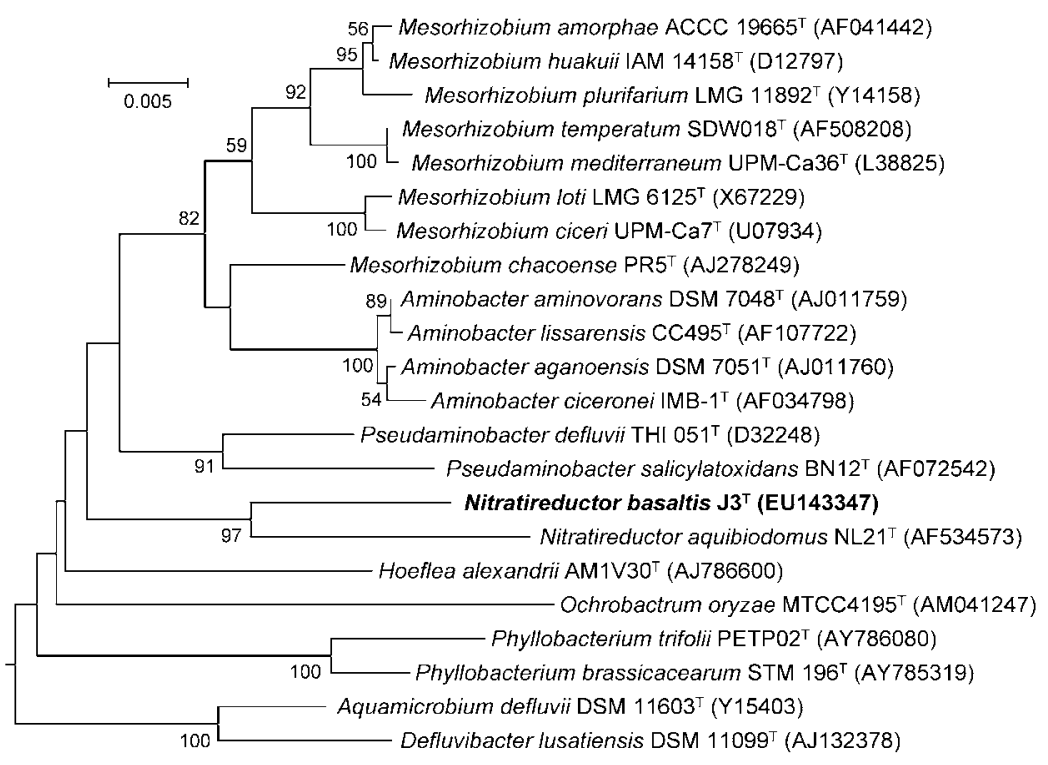

Fig. 1. Phylogenetic tree based on $16 \mathrm{~S}$ rRNA gene sequences showing the relationship between strain $\mathrm{J}^{\top}, N$. aquibiodomus $\mathrm{NL} 21^{\top}$ and representatives of related genera. The tree was constructed based on the neighbourjoining algorithm. Numbers indicate bootstrap values (\%) after 1000 resamplings; only values $>50 \%$ are shown. GenBank accession numbers are given in parentheses. Bar, 0.005 substitutions per site. 
Table 1. Fatty acid profiles of type strains of species of the genus Nitratireductor

Data for $N$. aquibiodomus $\mathrm{NL} 21^{\mathrm{T}}$ were taken from this study and Labbé et al. (2004). Values are percentages of total fatty acids. -, Not detected.

\begin{tabular}{|c|c|c|}
\hline Fatty acid & $\begin{array}{c}\text { N. basaltis } \\
\text { sp. nov. J3 } 3^{\mathrm{T}}\end{array}$ & $\begin{array}{c}\text { N. aquibiodomus } \\
\text { NL21 }^{\mathrm{T}}\end{array}$ \\
\hline \multicolumn{3}{|l|}{ Saturated } \\
\hline $\mathrm{C}_{16: 0}$ & 2.48 & $0.96-2.16$ \\
\hline $\mathrm{C}_{17: 0}$ & 0.88 & $0.33-1.72$ \\
\hline $\mathrm{C}_{18: 0}$ & 3.95 & $3.15-4.23$ \\
\hline $\mathrm{C}_{20: 0}$ & 0.17 & - \\
\hline \multicolumn{3}{|l|}{ Unsaturated } \\
\hline $\mathrm{C}_{17: 1} \omega 8 c$ & 0.37 & $0-0.59$ \\
\hline $\mathrm{C}_{17: 1} \omega 6 c$ & 0.37 & $0-0.54$ \\
\hline $\mathrm{C}_{18: 1} \omega 7 c$ & 81.93 & $75.01-76.47$ \\
\hline $\mathrm{C}_{18: 1} \omega 9 c$ & - & $0-0.61$ \\
\hline $\mathrm{C}_{20: 1} \omega 7 c$ & 0.27 & $0.48-0.63$ \\
\hline \multicolumn{3}{|l|}{ Branched } \\
\hline iso- $\mathrm{C}_{13: 0}$ & 0.28 & - \\
\hline iso- $\mathrm{C}_{15: 0}$ & 0.31 & - \\
\hline iso- $\mathrm{C}_{17: 0}$ & 2.86 & $1.93-3.25$ \\
\hline \multicolumn{3}{|l|}{ Hydroxy } \\
\hline iso- $\mathrm{C}_{15: 0} 3-\mathrm{OH}$ & 0.31 & $0.99-1.86$ \\
\hline $\mathrm{C}_{18: 0} 3-\mathrm{OH}$ & - & $0.31-0.52$ \\
\hline \multicolumn{3}{|l|}{ Cyclopropane acids } \\
\hline $\mathrm{C}_{19: 0} \omega 8 c$ cyclo & 4.25 & $9.35-12.14$ \\
\hline \multicolumn{3}{|l|}{ Other } \\
\hline Summed feature $3^{\star}$ & 1.58 & $0.56-0.63$ \\
\hline Summed feature $5 \dagger$ & - & $0-0.42$ \\
\hline Unknown & - & $1-1.12$ \\
\hline
\end{tabular}

${ }^{*}$ Summed feature 3 comprises iso- $\mathrm{C}_{15: 0} 2-\mathrm{OH}$ and/or $\mathrm{C}_{16: 1} \omega 7 c$. $\dagger$ Summed feature 5 comprises anteiso- $\mathrm{C}_{18: 0}$ and/or $\mathrm{C}_{18: 2} \omega 6,9 c$.

\section{Description of Nitratireductor basaltis sp. nov.}

Nitratireductor basaltis (ba.sal'tis. L. masc. gen. n. basaltis of basalt, pertaining to the source of isolation of the type strain).

Cells are Gram-negative, non-motile, coccoid or rodshaped $(0.6-0.7 \mu \mathrm{m}$ wide and $0.6-2.0 \mu \mathrm{m}$ long). Colonies are circular, smooth, creamy, convex and measure 0.5$2.0 \mathrm{~mm}$ in diameter after 3 days incubation on $\mathrm{MA}$ at $30{ }^{\circ} \mathrm{C}$. Cells grow at $15-45^{\circ} \mathrm{C}$, at pH $5.5-10.0$ and in $0-8 \%$ $\mathrm{NaCl}$. Growth occurs on R2A, TSA and MA. Positive for catalase, oxidase and valine arylamidase. Positive for the assimilation of $\mathrm{N}$-acetylglucosamine, L-arabinose, cellobiose, D- and L-fucose, gentiobiose, glycerol, gluconate, maltose, D-mannitol, melibiose, D-ribose, D-sorbitol and Dxylose; weakly positive for assimilation of 2-ketogluconate. Negative for assimilation of D-adonitol, starch, amygdalin, arbutin, D- and L-arabitol, dulcitol, aesculin ferric citrate, D-galactose, glycogen, inositol, 5-ketogluconate, D-lactose, D-xylose, D-mannose, melezitose, methyl $\alpha$-D-glucopyrano-
Table 2. Physiological characteristics of type strains of species of the genus Nitratireductor

Data for N. aquibiodomus NL21 ${ }^{\mathrm{T}}$ were taken from Labbé et al. (2004). Both strains are positive for nitrate reduction to nitrite, assimilation of D-glucose, and the presence of oxidase, catalase, alkaline phosphatase, esterase (C4), esterase lipase (C8), leucine arylamidase and naphthol-AS-BI-phosphohydrolase. Both strains are negative for nitrite reduction to nitrogen gas, indole production, gelatin hydrolysis, assimilation of caprate, erythritol, inulin, phenylacetate, L-rhamnose, salicin, trehalose and turanose and the presence of $\alpha$ chymotrypsin, $\alpha$-fucosidase, $\beta$-glucosidase, lipase (C14), $\alpha$-mannosidase and urease. + , Positive; $\mathrm{w}$, weakly positive; - , negative.

\begin{tabular}{|c|c|c|}
\hline Characteristic & $\begin{array}{c}\text { N. basaltis } \\
\mathrm{J3}^{\mathrm{T}}\end{array}$ & $\begin{array}{c}\text { N. aquibiodomus } \\
{\mathrm{NL} 21^{\mathrm{T}}}\end{array}$ \\
\hline Morphology & Coccoid, rods & Rods \\
\hline Motility & - & + \\
\hline $\mathrm{NaCl}$ tolerance $(\%)$ & $0-8$ & $0-5$ \\
\hline \multicolumn{3}{|l|}{ Assimilation of: } \\
\hline Gluconate & + & - \\
\hline Adipate & - & $\mathrm{w}$ \\
\hline Malate & - & $\mathrm{w}$ \\
\hline Citrate & - & + \\
\hline Sucrose & + & - \\
\hline D-Arabinose & - & + \\
\hline D-Fructose & - & + \\
\hline \multicolumn{3}{|l|}{ Activity of: } \\
\hline Cystine arylamidase & - & + \\
\hline Trypsin & $\mathrm{W}$ & + \\
\hline Acid phosphatase & - & + \\
\hline$\alpha$-Galactosidase & + & - \\
\hline$\beta$-Galactosidase & + & - \\
\hline$\beta$-Glucuronidase & $\mathrm{W}$ & - \\
\hline$\alpha$-Glucosidase & - & + \\
\hline$N$-Acetyl- $\beta$-glucosaminidase & - & + \\
\hline DNA G $+\mathrm{C}$ content $(\mathrm{mol} \%)$ & 56.7 & 57 \\
\hline
\end{tabular}

side, methyl $\alpha$-D-mannopyranoside, methyl $\beta$-D-xylose, raffinose, L-sorbose, D-tagatose, xylitol and L-xylose. Major fatty acids are $\mathrm{C}_{18: 1} \omega 7 c, \mathrm{C}_{19: 0} \omega 8 c$ cyclo and $\mathrm{C}_{18: 0}$. Other physiological and biochemical characteristics are shown in Tables 1 and 2.

The type strain is $\mathrm{J}^{\mathrm{T}}\left(=\mathrm{KCTC} 22119^{\mathrm{T}}=\mathrm{JCM} 14935^{\mathrm{T}}\right)$, isolated from black sand collected from Soesoggak beach, Jeju Island, Korea.

\section{Acknowledgements}

We thank Dr J. P. Euzéby for his valuable advice on nomenclature. This work was supported by the KRIBB Research Initiative Program, the Environmental Biotechnology National Core Research Center (KOSEF: R15-2003-012-02002-0) and the Conservation Technology Research and Development project hosted by the National Research Institute of Cultural Heritage of the Cultural Heritage Administration. The first author was supported by a Korea Research Foundation grant (MOEHRD, Basic Research Promotion Fund, KRF-2006-351-D00011). 


\section{References}

Buck, J. D. (1982). Nonstaining (KOH) method for determination of gram reactions of marine bacteria. Appl Environ Microbiol 44, 992-993.

Felsenstein, J. (1985). Confidence limit on phylogenies: an approach using the bootstrap. Evolution 39, 783-791.

Gonzalez, J. M. \& Saiz-Jimenez, C. (2002). A fluorimetric method for the estimation of $\mathrm{G}+\mathrm{C} \mathrm{mol} \%$ content in microorganisms by thermal denaturation temperature. Environ Microbiol 4, 770-773.

Kim, K. H., Ten, L. N., Liu, Q. M., Im, W. T. \& Lee, S. T. (2006). Sphingobacterium daejeonense sp. nov., isolated from a compost sample. Int J Syst Evol Microbiol 56, 2031-2036.

Kimura, M. (1980). A simple method for estimating evolutionary rates of base substitutions through comparative studies of nucleotide sequences. J Mol Evol 16, 111-120.

Kumar, S., Tamura, K. \& Nei, M. (2004). MEGA3: integrated software for molecular evolutionary genetics analysis and sequence alignment. Brief Bioinform 5, 150-163.

Labbé, N., Juteau, P., Parent, S. \& Villemur, R. (2003). Bacterial diversity in a marine methanol-fed denitrification reactor at the Montreal Biodome, Canada. Microb Ecol 46, 12-21.

Labbé, N., Parent, S. \& Villemur, R. (2004). Nitratireductor aquibiodomus gen. nov., sp. nov., a novel $\alpha$-proteobacterium from the marine denitrification system of the Montreal Biodome (Canada). Int J Syst Evol Microbiol 54, 269-273.
Mergaert, J. \& Swings, J. (2005). Family IV. Phyllobacteriaceae fam. nov. In Bergey's Manual of Systematic Bacteriology, 2nd edn, vol. 2, part C, p. 393. Edited by D. J. Brenner, N. R. Krieg, J. T. Staley \& G. M. Garrity. New York: Springer.

Mergaert, J. \& Swings, J. (2006). Family IV. Phyllobacteriaceae fam. nov. In List of New Names and New Combinations Previously Effectively, but not Validly Published, Validation List no. 107. Int J Syst Evol Microbiol 56, 1-6.

Roh, S. W., Sung, Y., Nam, Y. D., Chang, H. W., Kim, K. H., Yoon, J. H., Jeon, C. O., Oh, H. M. \& Bae, J. W. (2008). Arthrobacter soli sp. nov., a novel bacterium isolated from wastewater reservoir sediment. J Microbiol 46, 40-44.

Saitou, N. \& Nei, M. (1987). The neighbor-joining method: a new method for reconstructing phylogenetic trees. Mol Biol Evol 4, 406425.

Sasser, M. (1990). Identification of bacteria by gas chromatography of cellular fatty acids. MIDI Technical Note 101. Newark, DE: MIDI Inc.

Thompson, J. D., Gibson, T. J., Plewniak, F., Jeanmougin, F. \& Higgins, D. G. (1997). The CLUSTAL_X windows interface: flexible strategies for multiple sequence alignment aided by quality analysis tools. Nucleic Acids Res 25, 4876-4882.

Yoon, J. H., Lee, S. T. \& Park, Y. H. (1998). Inter- and intraspecific phylogenetic analysis of the genus Nocardioides and related taxa based on 16S rDNA sequences. Int J Syst Bacteriol 48, 187-194. 